\title{
Consumption of Fat, Protein, and Carbohydrate Among Adolescent with Overweight / Obesity
}

\author{
Reny Tri Febriani'), Ady Soesetidjo²), Farida Wahyuning Tiyas3) \\ 1)Masters Program in Public Health, Universitas Jember \\ 2)Faculty of Public Health, Universitas Jember \\ 3)Faculty of Dentistry, Universitas Jember
}

\begin{abstract}
Background: Excessive nutritional status is a problem related to food, nutrition and public health globally which increases its prevalence quickly and can occur in all aspects of life. The increasing prevalence of excessive nutritional status is a time bomb for some countries that can explode in the future both in terms of health, mental and economic impacts for countries that are associated with increased health costs. Consumption levels such as fat, protein and carbohydrates affect excessive nutritional status, the excessive fat intake for a long time can cause overweight / obesity.

Subjects and Method: The design of the study is analytic observation including a total of 111 teens who are overweight and obese. The sampling technique is random sampling. The analysis was conducted using smartpls version 3 .

Results: Diet had a positive effect on overweight $(b=2.18 ; p=0.032)$ and level of food consumption $(b=2.33 ; p=0.022)$. High level of fat, protein, and carbohydrates consumption had a positive effect on overweight among adolescents $(b=11.54 ; p<0.001)$.

Conclusions: Diet has a positive effect on overweight and level of food consumption. High level of fat, protein, and carbohydrates consumption has a positive effect on overweight among adolescents.
\end{abstract}

Keywords: diet, fat, protein, carbohydrate, overweight, obesity, adolescent

\section{Corresspondence:}

Reny Tri Febriani. Masters Program in Public Health, Universitas Jember.

Email: reny.smkfmaharani@gmail.com.

\section{BACKGROUND}

$\overline{\text { Excessive nutritional status is a problem }}$ related to food, nutrition and global public health which is rapidly increasing in its prevalence and can occur in all walks of life (Toruan, 2007; Bredbenner et al., 2011; Ministry of Health, 2013; Cussler et al., 2011; Morgan and Scott, 2014). Excessive nutritional status in this case according to Persagi RSCM is overweight and obese. Obesity rates increase every year in various age groups, including adolescents. Obesity in adolescent groups appears to be an alarming increase (Scerri and Ventura, 2010).
The increase of prevalence of the excessive nutritional status is a time bomb for countries that can explode in the future both in terms of health, mental adolescence and the economic impact of the state associated with increased health costs of obesity-related diseases (Wahyu, 2009). The decrease of the number of $\mathrm{T}$ cells in the body which results in a decrease in immunity (Belger, 2017), cognitive problems occur in obese adolescents in which obese adolescents experience cognitive slowdown (Sweat et al., 2017).

The prevalence of excessive nutritional status in 2013 in the world amounted to 2.1 billion. Indonesia is among the top 10 
with 40 million people or the equivalent of the entire population of West Java. Data from the American Heart Association (AHA) in 2011, there were 12 millions children aged 2-19 years (16.3\%) and 72 million adults (32.9\%) Americans are obese (Nussy et al., 2014).

In Indonesia, the results of the 2013 Riskesdas showed that the prevalence of excess nutritional status in adolescents aged $16-18$ years amounted to $7.3 \%$ consisting of $5.7 \%$ over-weight and $1.6 \%$ obesity. The tendency of the prevalence of excessive nutritional status to increase is from $1.4 \%$ (in 2010) to $7.3 \%$ (in 2013). The prevalence of excessive nutritional status in urban areas is higher than in rural area which is $1.8 \%$ in cities and $0.9 \%$ in rural areas (Ministry of Health, 2013).

Consumption levels such as fat, protein and carbohydrates affect the excessive nutritional status, fat intake that exceeds the need for a long period of time can lead to obesity, protein consumed more than the body's needs will be changed and stored as fat. Excessive carbohydrates in the body will be converted into fat and stored in the body so that it can cause weight gain. Adolescents are chosen as the target population because the population accounts for one-fifth of the total population. Teens are the next generation of the nation so that they are one of the most potential and qualified human resources if their nutritional needs are fulfilled early

Table 1. Characteristics of adolescents based on age and gender

\begin{tabular}{llcc}
\hline \multirow{2}{*}{ Variable } & \multicolumn{1}{c}{ Classification } & N & Total \\
\cline { 3 - 4 } Age (year) & $12-15$ & 31 & 27.9 \\
\multirow{2}{*}{ Gender } & $16-18$ & 80 & 72.1 \\
& Female & 61 & 55.0 \\
& Male & 50 & 45.0 \\
\hline
\end{tabular}

Table 2 shows food recall frequency distribution of $2 \times 24$ hours of consumption
(Ramadani, 2005 in Sari, 2012).

The high prevalence of excessive nutritional status in Malang also occurred because Malang became a city of education, so it became a new alternative to education, starting from the elementary level up to college. There are various types of schools in Malang to meet the educational needs of various levels of society. Some favorite secondary schools are located in the middle of the city which is close to shopping centers and culinary centers. It also changes the lifestyle of students who become more consumptive, including in terms of changing food choices.

\section{SUBJECTS AND METHOD}

This study is observational analytic with cross sectional approach. This research was conducted at Malang Public Senior High School. A sample of 111 high school students was selected by random sampling. The data were collected by a $2 \times 24$ hour food recall questionnaires. The data were analyzed with smartpls version 3 .

RESULTS
The results of measurements carried out
with $2 \times 24$ hour food recall are shown in
table 1 . Based on the table 1, most of the
adolescents were at age 16-18 years
$(72.10 \%)$ and $55 \%$ were female.

level among adolescents. Based on the table 2 , most levels of fat consumption amounted 
to 33 adolescents (29.7\%) above the RDA category, the majority of protein consumption levels amounted to 32 adolescents (28.8\%) with normal categories, and for the carbohydrate consumption levels, it amounted to 43 adolescents (38.7\%) with severe deficit category.

Table 2. Food recall frequency distribution of $2 \times 24$ hours of consumption level

\begin{tabular}{clcc}
\hline \multirow{2}{*}{ Variable } & \multicolumn{1}{c}{ Classification } & N & Total \\
\cline { 3 - 4 } Fat Consumption & Nevere deficit & 25 & 22.5 \\
& Moderate deficit & 24 & 21.6 \\
& Light deficit & 7 & 6.3 \\
& Normal & 22 & 19.8 \\
& Above RDA & 33 & 29.7 \\
& Severe deficit & 29 & 26.1 \\
Protein & Moderate deficit & 6 & 5.4 \\
Consumption & Light deficit & 19 & 17.1 \\
& Normal & 32 & 28.2 \\
& Above RDA & 25 & 22.5 \\
& Severe deficit & 43 & 38.7 \\
Carbohydrate & Moderate deficit & 17 & 15.3 \\
Consumption & Light deficit & 9 & 8.1 \\
& Normal & 27 & 24.3 \\
& Above RDA & 15 & 13.5 \\
\hline
\end{tabular}

Table 3 shows the distribution of fat consumption level. Based on table 3, consumption of breakfast menu for fat consumption in 37 adolescents (33.3\%) had a moderate deficit category. A total of 33 adolescents (29.3\%) chose the lunch menu containing fat above the NAR. There were 30 adolescents (27.0\%) who ate dinner which contained fat above the NAR.

Table 3. The distribution of fat consumption level

\begin{tabular}{lllc}
\hline \multirow{2}{*}{ Variables } & Classification & \multicolumn{2}{c}{ Total } \\
\cline { 2 - 4 } & Heavy deficit & n & \% \\
\hline \multirow{3}{*}{ Morning Fat } & Moderate deficit & 24 & 21.6 \\
Consumption & Mild deficit & 37 & 33.3 \\
& Normal & 17 & 15.3 \\
& Above the NAR & 16 & 14.4 \\
& Heavy deficit & 17 & 15.3 \\
Daytime Fat & Moderate deficit & 20 & 18.0 \\
Consumption & Mild deficit & 23 & 20.7 \\
& Normal & 13 & 11.7 \\
& Above the NAR & 22 & 19.8 \\
Evening Fat & Heavy deficit & 33 & 29.3 \\
Consumption & Moderate deficit & 20 & 18.0 \\
& Mild deficit & 24 & 21.6 \\
& Normal & 14 & 12.6 \\
\hline
\end{tabular}

Table 4 shows the distribution of protein consumption level. Based on table 4, consumption of breakfast menu for protein in
40 adolescents (36.0\%) was at normal category. As many as 35 adolescents (31.5\%) ate lunch with normal protein level. A total of 
32 adolescents (28.8\%) ate dinner which

contained protein in normal category.

Table 4. The distribution of protein consumption level

\begin{tabular}{llcc}
\hline \multirow{2}{*}{ Variables } & Classification & n & Total \\
\cline { 2 - 4 } & & 25 & \% \\
\hline \multirow{3}{*}{ Morning Protein } & Heavy deficit & 6 & 22.5 \\
Consumption & Mild deficit & 18 & 5.4 \\
& Normal & 40 & 16.2 \\
& Above the NAR & 22 & 36.0 \\
& Heavy deficit & 16 & 19.8 \\
Daytime Protein & Moderate deficit & 7 & 14.4 \\
Consumption & Mild deficit & 19 & 6.3 \\
& Normal & 35 & 17.1 \\
& Above the NAR & 34 & 31.5 \\
Evening Protein & Heavy deficit & 19 & 30.6 \\
Consumption & Moderate deficit & 7 & 17.1 \\
& Mild deficit & 28 & 6.3 \\
& Normal & 32 & 25.2 \\
\hline
\end{tabular}

Table 5 shows the distribution of carbohydrate consumption level. Based on table 4, consumption of breakfast menu for carbohydrate in 33 adolescents (29.3\%) was at heavy deficits category. A total of 36 adolescents (32.4\%) consumed lunch with carbohydrate level above the NAR. A total of 43 adolescents $(38.7 \%)$ ate dinner which contained carbohydrates with a heavy deficit category.

Table 5. The distribution of carbohydrate consumption level

\begin{tabular}{llcc}
\hline \multirow{2}{*}{ Variables } & Classification & n & Total \\
\cline { 2 - 4 } Morning & Heavy deficit & 48 & \% \\
Carbohydrate & Moderate deficit & 19 & 43.2 \\
Consumption & Mild deficit & 9 & 17.1 \\
& Normal & 23 & 8.1 \\
& Above the NAR & 12 & 20.7 \\
Daytime & Heavy deficit & 16 & 10.8 \\
Carbohydrate & Moderate deficit & 16 & 14.4 \\
Consumption & Mild deficit & 10 & 14.4 \\
& Normal & 33 & 9.0 \\
& Above the NAR & 36 & 29.7 \\
Evening & Heavy deficit & 43 & 32.4 \\
Carbohydrate & Moderate deficit & 25 & 38.7 \\
Consumption & Mild deficit & 10 & 22.5 \\
& Normal & 25 & 9.0 \\
\hline
\end{tabular}

The results of interviews with 10 school health center coordinators stated that all students used online applications to ease them to order food from outside the school during rest time. The types of food ordered include fast food. Food recall results during school showed that fat consumption was above NAR (33 adolescents, 29.3\%) and carbohydrate consumption above NAR (36 adolescents, 32.4\%). Table 6 showed frequency distribution of adoles- 
cent diet. Table 6 shows that 60 adolescents

(54.1\%) were on diet.

Table 6. Frequency Distribution of Adolescent Diets

\begin{tabular}{lcc}
\hline \multirow{2}{*}{ Classification } & \multicolumn{2}{c}{ Total } \\
\cline { 2 - 3 } Diet & 60 & \% \\
Not Diet & 51 & 54.1 \\
\hline
\end{tabular}

Table 7. The results of analysis of the effect of the consumption level on high nutritional status

\begin{tabular}{lllcc}
\hline \multicolumn{1}{c}{ Dependent Variable } & & Independent Variable & b & p \\
\hline High Nutritional Status & $\leftarrow$ & Diet & 2.18 & 0.032 \\
Food Consumption Level & $\leftarrow$ & Diet & 2.33 & 0.022 \\
High nutritional status & $\leftarrow$ & Consumption Level & 11.54 & $<0.001$ \\
\hline
\end{tabular}

Table 5 showed the results of analysis of the effect of consumption level on high nutritional status. Table 5 showed that the diet has a positive effect on high nutritional status $(b=2.18 ; p=0.032)$. Diet has a positive effect on the level of food consumption $(b=2.33 ; p=0.022)$. The level of consumption of foods high in fat, protein, and carbohydrates has a positive effect on high nutritional status among adolescents $(b=$ 11.54; $\mathrm{p}<0.001)$.

\section{DISCUSSIONS}

Based on the result of analysis, there was an effect of diet on high nutritional status through the level of food consumption. Most of the adolescents (54.10\%) were on diet. A diet was a limitation on the consumption of certain foods for the amount, type, or frequency of eating that can be aimed at losing weight. The result of this study was in line with Nusa (2012) who stated that there was a relationship between weight-increasing diets and diets which limit the food consumption and body calorie needs.

Makris (2011) stated that dietary guidelines which based on evidence that consuming an LF diet (20-35\%) could help to regulate body weight, improve health, and reduce the risk of chronic diseases. The guidelines include recommendations for "foods that must be reduced" (i.e. saturated and trans fats, cholesterol, sodium, additional sugar, alcohol) and "food for improvement" (i.e. fruits, vegetables, seeds) grains, low-fat milk, protein, and oil) to maximize the nutritional and health content that promoted food potential. Calorie restriction strategies were one of the most common diet plans to reduce obesity.

Based on the result of analysis, there was an effect of the level of consumption of fats, proteins and carbohydrates on high nutritional status. Most adolescents (29.70\%) have fat consumption levels above the NAR, (32\%) and have sufficient levels of protein consumption. Adolescents consumed high amounts of fat and carbohydrates at lunch. Many adolescents used the online food ordering application to buy lunch. The selection of foods chosen was fast food which contained high fat and carbohydrate content. Excess fat in the body showed that excessive fat intake has an effect on fat tissue. Fat intake that exceeded the need for a long time could lead to obesity. High-fat foods have a delicious taste and low filling ability, so people can consume them excessively. Excess protein in the body would be stored as fat. Excess carbohydrates would also be stored as fat if they were not used as energy. Therefore, consuming excess food 
sources of fat, protein, and carbohydrates lead to an increase in body weight.

The result of this study was in line with studies done by Iqbal (2013), Weni (2015), Savitri (2015), and Mokolensang (2016) which stated that there was a relationship between the level of consumption of fats, proteins and carbohydrates with high nutritional status. According to Kharismawati (2010), adolescents with fat intake in the heavy category were 4.4 times more likely to have obesity than adolescents with low levels of fat intake. Protein has an important role in heavy weight. The human body cannot store excess protein, the protein consumed which exceeded the needs would be changed and stored as fat. If someone consumed a large amount of extra protein, it was very possible to gain weight. The result of a study done by Kharismawati (2010) showed that there was a relationship between the level of protein intake and obesity status, but the relationship was not statistically significant. Research subjects with more protein intake were 6 times more likely to have obesity than research subjects with sufficient levels of protein intake. Proteins in excess conditions would experience deaminase or release of amino groups (NH2) from amino acids. Nitrogen was released from the body and the remains of carbon bonds were converted to acetyl CoA. Acetyl CoA can then be synthesized into triglycerides through the process of lipogenesis. Therefore, if someone consumed a lot of protein in his/her diet which can be used by his/her tissue, most of this excessive amount was stored as fat.

Carbohydrates or excess glucose would be stored in the liver in the form of glycogen. Muscle cells also stored the glucose in the form of glycogen. This glycogen was only used as energy for muscle purposes and cannot be returned as glucose into the bloodstream. The body can only store glycogen in a limited amount, which was for energy purposes for several hours. If carbohydrate intake exceeded the body's oxidative capacity and storage, the cells could convert the carbohydrates into fat. This change occurred in the heart. This fat was then taken to fat cells which could store unlimited amounts of fat.

Based on the results of the analysis, it can be concluded that there was an effect of diet on over weight/obesity. Diet has a positive effect on the level of food consumption. The level of food consumption has an effect on over weight/obesity.

\section{REFERENCES}

Berger S, Ceccarini G, Scabia G, Barone I, Pelosini C, Ferrari F, Magno S, Dattilo A, et al. (2017). Lipodystrophy and Obesity Are Associated With Decreased Number of T Cells With Regulatory Function and Pro-Inflammatory Macrophage Phenotype. Int J Obes (Lond). 41(11): 1676-1684. doi: 10.1038/ijo.2017.163.

Iqbal UM (2013). Hubungan Konsumsi Lemak Dengan Kejadian Obesitas Orang Dewasa Di Kota Dan Kabupaten Bogor. Skripsi. Departemen Gizi Masyarakat. Fakultas Ekologi Manusia. Institut Pertanian Bogor.

Kemenkes RI (2013). Riset Kesehatan Dasar Tahun 2013. Jakarta: Balitbangkes Kemenkes RI.

Kharismaswati R (2010). Hubungan Tingkat Asupan Energi, Protein, Lemak, Karbohidrat, Dan Serat Dengan Status Obesitas Pada Siswa SD. Skripsi. Program Studi Ilmu Gizi Fakultas Kedokteran Universitas Diponegoro Semarang.

Kurdanti W, Suryani I, Syamsiatun NH, Siwi LP, Adityanti MM, Mustikaningsih D, Sholihah KI (2015). Faktor - Faktor yang Mempengaruhi Obe- 
sitas pada Remaja. Jurnal Gizi Klinik Indonesia. 11(04): 179 - 190. Doi: https://doi.org/10.22146/ijen.22900

Makris A, Foster GD (2011). Dietary Approaches to the Treatment of Obesity. in PMC Psychiatr Clin North Am. 34(4): 813-827. doi: 10.1016/j.psc.2011.08.004.

Maulinda WN (2017). Analisis Faktor Faktor Terjadinya Osteoarthritis Lansia di Posyandu Lansia Kelurahan Bareng Kota Malang. Skripsi. Kementerian Kesehatan Republik Indonesia Politeknik Kesehatan Malang. Jurusan Gizi Program Studi Diploma IV Gizi Malang.

Mokolensang OG, Manampiring AE, Fatimawali (2016). Hubungan Pola Makan Dan Obesitas Pada Remaja Di Kota Bitung. Jurnal e-Biomedik (eBm), 4(1): 128-135.

Moreno LA, González-Gross M, Kersting M, Molnár D, de Henauw S, Beghin L, Sjöström M, Hagströmer M (2007). Assessing, Understanding and Modifying Nutritional Status, Eating Habits and Physical Activity in European Adolescents: the HELENA (Healthy Lifestyle in Europe by Nutrition in Adolescence) Study. Public Health Nutrition: 11(3): 288-299. Doi: 10.1017/S1368980007000535.

Nusa AFA (2017). Hubungan Faktor Perilaku, Frekuensi Konsumsi Fast Food, Diet dan Genetik dengan Tingkat Kelebihan Berat Badan. Media Gizi Indonesia. 9(1).

Nussy CY, Ratag GA, Mayulu N (2014). Analisis Upaya-Upaya Penurunan
Berat Badan Pada Mahasiswi Angkatan 2010. Fakultas Kedokteran Universitas Sam Ratulangi Manado. Jurnal Kedokteran Komunitas dan Tropik. 2 (2): 81-84.

Putri, Alvina Y (2015). Faktor - Faktor yang Berhubungan dengan Pola Konsumsi Makan pada Siswa Madrasah Ibtidaiyah Unwanul Huda di Jakarta Selatan. Skripsi. Peminatan Gizi Program Studi Kesehatan Masyarakat Fakultas kedokteran dan Ilmu Kesehatan. Universitas Islam Negeri Syarif Hidayatullah Jakarta.

Rahmawati AC, Zulaekah S, Rahmawaty S (2009). Aktivitas fisik dan rasio kolesterol (HDL) pada penderita penyakit jantung koroner di Poliklinik Jantung RSUD Dr. Moewardi Surakarta. Jurnal Kesehatan, 2(1): 11-18.

Savitri W (2015). Hubungan Body Image, Pola Konsumsi Dan Aktivitas Fisik Dengan Status Gizi Siswi Sman 63 Jakarta. Skripsi. Peminatan Gizi Program Studi Kesehatan Masyarakat Fakultas Kedokteran Dan Ilmu Kesehatan Universitas Islam Negeri Syarif Hidayatullah.

Scholz U, Ochsner S, Luszczynska A, Springs C (2013). Interventions on Changes in Fat Consumption in Controlled Trial. International Journal. 48(4), 604-615.

Wati DK (2017). Perbedaan Body Image, Pola Konsumsi Dan Kebiasaan Olahraga Antara Remaja Putri Overweight Dengan Remaja Putri Non-Overweight Di SMPK Santa Agnes Surabaya. Thesis. Universitas Airlangga. 